\title{
The Effect of Time Management Practice on the Academic Achievement: A Case of Dire Dawa University, Ethiopia
}

\author{
Tesfaye Nigussie \\ Injibara University: College of Business and Economics, Department of marketing management, p.o.box 040, \\ Injibara, Ethiopia
}

\begin{abstract}
The aim of the study or the research was to assess general time management practice /behavior of regular program students of Dire Dawa University and its association with their academic achievement, gender, and year of study. The research was conducted on Dire Dawa University the school business and economics regular program student. The total population of the study was 998 . Therefore, the researcher employed proportionate stratified random sampling technique on the basis of the student's year of study and academic achievement measured in terms of CGPA. The sample size was 120 students. The study predominantly sticks on primary data. The time management questionnaire developed by Britton and Tesser (1991) was used to measure time management behavior of participant students. Descriptive statistics was used to generate means, standard deviation and frequencies for the study variables, the prevalence of exposure conditions were checked for different sub-groups of the questionnaire and difference is was tested by using chi-square test. The result of this study showed that most students $45(35 \%)$ and $42(35 \%)$ possess time management score at moderate and high level respectively. With respect to gender difference is in time management, the result revealed that male students score in time management (mean score $=55.72$ ) were higher than female $(50.5)$ students. With respect to the significance association between time management and academic achievement (CGPA), it was found in this study that the better students time management behavior, the higher the students CGPA. With respect to year of study, the results showed that the student's general time management score were no significantly different between students due to year of study. Generally, this study underscores the importance of understanding the role time management in academic achievement. Certainly those who are unable to manage time well may be at risk for underachievement.
\end{abstract}

Keywords: General time management, Academic achievement, Student

DOI: $10.7176 / \mathrm{EJBM} / 11-4-05$

\section{Introduction}

Time management is considered as an inclusive process that is done through administrative functions which is deeply dependent on high personal talents and skills so it can then produce positive effects to society and individual at the same time. Nonetheless, all of that must be restricted to a specified period of time in order to make persons adjust with present and future situations (Alghamdi, 2008, p30). It is of importance to point out to the fact by (Alsalmi, 2008, p25) that the more the company is able to manage time effectively, the more it fulfills its aims correctly in the right time.

Time management is very worthwhile issue during to being it a key factor in any success at all levels of life and for that the term time management is strongly associated with administrative work. Despite of its importance, it is never an easy task to manage time individually and a need to specific qualifications along with many personal skills is then a must. Let alone exploiting the available resources in order to meet the society and individual needs at the same time and the ability to adjust with the present and future situations (Alghamdi, 2008, p 49).

\subsection{Statement of the problem}

In this era of globalization and technological revolution, education is considered as a first step for every human activity. It plays a vital role in the development of human capital and is linked with an individual's well-being and opportunities for better living (Battle \& Lewis, 2002). It ensures the acquisition of knowledge and skills that enable individuals to increase their productivity and improve their quality of life. This increase in productivity also leads towards new sources of earning which enhances the economic growth of a country (Saxton, 2000). Time management plays a vital role in improving student's academic performance and achievements. Each and every student should have time management ability which includes setting goals \& priorities, using time management mechanism and being organized in using time.

In developing countries where students have a lot of issues during academic journey have a new story for the researcher to dig out much more interesting results. Time management practices have an impact on the results of students as empirical studies done by past researchers. In spite of knowing about the impact of time on academic achievement, this relationship is not given importance by the students (Sevari \& Kandy, 2011). Therefore Time management has a significant impact on the lives of the students commonly for those who are 
studying in the higher education institutions where there is no existence of parent and teacher supervision. It is better to conduct research to create broaden awareness on the effect of time management for the students and others. The ultimate goal of this research is to examine the effect of time management practices on academic achievement of university student.

\subsection{Objectives of the study}

$>$ To assess the prevalence level of time management of the university

$>$ To identify whether there is any significant differences in time management, scores among the university students in relation with year of study, gender and academic achievement

$>$ To examine the contribution of efficient and effective use of time for academic achievement.

$>$ To investigate the relationship among general time management, short range planning, time attitudes and long range planning among the university students.

\section{Literature review}

Time management is an important is sue to both college students and educators. Educators are concerned that students spend sufficient time, especially study time, on academics, while students are concerned with meeting the numerous demands on their time. As Macan et al. (p. 760) explains, "In trying to read all the books and chapters assigned, meet paper deadlines, and participate in extracurricular activities, college students may become overwhelmed with feelings that there is not enough time to complete all their work adequately." Given this time pressure, successful time management is considered important by college students. "Indeed, a survey showed that $67 \%$ of the undergraduates at our university reported that their greatest personal need (of 40 needs on a checklist) was 'to manage my time more effectively"' (qtd. in Britton and Tesser, p. 406).

Time is to be deemed very substantial to human beings as age and capital; especially that entire human life is made of time segments which mean the second that is gone is going to shorten the human life and make the death nearer. The whole life is a test to see who deserves the paradise in the judgment day, so exploiting the time to fulfill ambitions is of great importance in both worldly life and in the hereafter (Algaradawi, 2003, p14). Time management is very worthwhile issue during to being it a key factor in any success at all levels of life and for that the term time management is strongly associated with administrative work. Despite of its importance, it is never an easy task to manage time individually and a need to specific qualifications along with many personal skills is then a must. Let alone exploiting the available resources in order to meet the society and individual needs at the same time and the ability to adjust with the present and future situations (Alghamdi, 2008, p 49).

Time management is considered as an inclusive process that is done through administrative functions which is deeply dependent on high personal talents and skills so it can then produce positive effects to society and individual at the same time. Nonetheless, all of that must be restricted to a specified period of time in order to make persons adjust with present and future situations (Alghamdi ,2008,p30). It is of importance to point out to the fact by (Alsalmi, 2008, p25 ) that the more the company is able to manage time effectively, the more it fulfills its aims correctly in the right time. And for the sake of effectiveness, one must give priorities to some tasks over the others in order to distribute the sufficient time to get the best results, and effectiveness can be then measured by the quantity of finished tasks in that specified time.

A study by Alrheme and Almardeni (2014) aimed at identifying the students' viewpoint about how to time in terms of planning, organizing, directing and censorship and its effect on academic achievement as long as identifying the personal variables effects on academic achievement. The data were collected through a sample of 300 students. The study results showed that the planning was of high effect on academic achievement proved by a correlation coefficient and that there is a statistically significant positive relationship between time management and academic achievement. Kimlglo \&filz(2008) conducted a study which aimed at studying the relation between the academic achievement and time management skills in education college at ghazi university in turkey. The study results also showed that the student's behavior in the field of planning time was at a high level, in the area of wasting time it was at its lowest. It also showed the existence of significant positive relationship between planning time and wasting time and between the academic achievements of students and there is a meaningful relationship between the medium time management and academic achievement as well. Abusakour (2003) conducted a study which aimed at finding the Obstacles of time management and decisionmaking to the education departments of government schools in the West Bank, Palestine through detecting the obstacles of time management and decision-making to the education departments of government secondary schools and developing of suitable suggestions to reduce them. The researcher has used the descriptive approach in his study in the collection of information and data, the study results showed that the obstacles of 
time management relate directly to the obstacles in planning in addition to the shortage in resources and the retardation of scholastic services in the next year.

Abulshawi \& Abusultana (2003) conducted a study aiming at recognizing the student of yarmouk university ability to manage time from different faculties and identifying its relation to academic achievement considering the variables; gender, the university year and the faculty and how much these variables affect time management skills. The study results showed that there is a medium degree of time management skill among students at Yarmouk University, and the skill of time management and academic achievement. And that there is a positive correlation and statistically important between time management skill and the academic achievement according the faculty variable goes to the advantage of economics, science students only.

\subsection{Dimensions of time management}

The effectual utilizing of time and managing time requires procedures and good quality planning behaviors. One can make use of time effectively and competently by keeping time logs, setting immediate and longstanding goals, prioritizing responsibilities, constructing to-do lists and arrangement, and organize one's workspace, as studies of earlier period and plentiful how-to books proposed (Sabelis, 2001). Time saving techniques and behaviors can be categorized into numerous groups and be liable to contribute to a number of fundamental qualities in general. There are three surfaces of time management behaviors: short-range planning, long- range planning and time attitudes (Laurie \& Hellsten, 2002). Short-range planning is the capability to set out and systematize responsibilities in the short period of time. Long-range planning competence is to handle everyday jobs over a longer time perspective by keeping follow of significant dates and setting objectives by putting adjournment (Alay \& Koçak, 2003).

\subsubsection{Long range planning}

Long-range planning means to have long-range objectives and having disciplined routines. Various researchers named it as having perception of a preference for organization and it is comparable to long range planning. To acquire a summary on the everyday jobs that necessitate to be executed, time limits and priorities which increases the perception of having control over time so, in the long run, planning enables one to deal with all activities (Kelly, 2004). It directs to have less perception of control over time because it may be tackling to be familiar with how much effort requires to be completed within hours, days or weeks; it may even be the immediately measurable effect of planning. This gives the impression to indicate that time management practices accomplish to have an influence on educational achievement, but that's not all they affect (Brigitte et al., 2005). It was also found that the students had advanced overall academic achievements who accounted using goaloriented time management practices.

According to "Britton and Tesser, (1991)" those who scored 58 and above points have better time management practice, those who scored 48-57 points have moderate time management practice and those who scored 48 below points have low time management practice.

\subsubsection{Short range planning}

Short-range planning was defined as time management activities surrounded by daily or weekly time structure and cover the activities such as setting objectives at the commencement of the day, planning and prioritizing daily behaviors and creation work contents (Yilmaz et al., 2006). Numerous studies invented that short-range planning behavior, forecasting of time in the short run, surrounded by the time enclose of a week or less, established a constructive relationship to grade point average. Short range planning in interface with accomplishment determined was optimistically associated to dealing performance as well (Noftle et al., 2007). Likewise, most of the studies that control for the student time do so by determining total time committed to the course, a variable normally found to be unimportant. Academic achievement means the educational objective that is accomplished by a student, teacher or institution realize over a definite short period (Lisa \& Robert, 2008). In a different research finding it has been demonstrated that there exists a positive significant relation between students' grade point averages and the time attitudes and the short-range planning.

\subsubsection{Time attitudes}

Time management demands a key shift in emphasis: concentrate on results, not on being busy. There are a lot of cases with people who waste their lives in discolored doings and attain very small since they are placing their labors into the incorrect responsibilities or weakening to focus their activity successfully, established that two time management workings directly affect the collective academic achievements (Mercanlioglu, 2010). The perception of how their time requires to be used up or planning including utilizing short and long period goals and time attitudes or students accomplished that both planning and encouraging time attitudes initiated that they had much more time to finish their everyday jobs because they experiences more in control of how their time was exhausted therefore knowing when they had to state no to activities (Kaushar, 2013). The literature revealed that time management practices that connected to the individual's awareness and attitudes about time management and is comparable the perception of having control over time. Therefore, time attitudes comprise the perception that the individual is in control of time the perception that the person is efficiently managing his 
time and the perception that the individual is making constructive utilization of time (Karim et al., 2015).

\section{Research methodology}

\subsection{Research design}

Accordingly, from different types of research designs descriptive type of research design was employed for this paper for the realization of intended objectives to describe the time management effect to the academic achievements of students. This research design is a fact finding study with adequate and accurate interpretation of findings and furthermore, it allows describing both qualitative and quantitative approaches (Kothari, 2004). The researcher employed adopted questionnaire developed by 'Britton and Tessor (1991) in relation with time management dimensions (time attitude, short range planning and long range planning). Proportionate stratified random sampling technique was employed.

\subsection{Sampling design and techniques}

To determine the sample size, the researcher was employed proportionate stratified random sampling technique on the basis of year of study and academic achievement measured in terms of cumulative Grade. With stratified random sampling, there would an equal chance that second and third year students could be selected for inclusion in each stratum of the sample and also to have proportional number of students. Total number of students of the college was 998. To determine the sample, the researcher employed single population proportion formula developed by (Kish and Leslie, 1965).

$\mathrm{n}=$ no

$\underline{1+\text { no }}$

$\mathrm{N}$

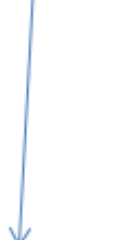

Therefore,

$$
\underline{1+96}=96
$$

998

$$
\begin{aligned}
& \begin{array}{l}
\longrightarrow \text { where } \quad \mathrm{no}=\frac{\mathrm{Z}^{2} \cdot \mathrm{p} \cdot \mathrm{q}=\frac{1.96^{2 *} 0.5^{*} 0.5}{\mathrm{e}^{2}}=96}{(0.1) 2} \\
\mathrm{~N}=\text { total population } \\
\mathrm{Z}=\text { level of confidence }(1.96) \\
\mathrm{n}=\text { sample size } \\
\mathrm{p}=\text { proportion } \mathrm{p}(0.5) \& \mathrm{q}(0.5)
\end{array} \\
& \mathrm{e}=\text { error term of precision measurement }(0.1)
\end{aligned}
$$

While determining sample size the researcher would have the fear of non-response rate which is $15 \%$ and design effect, which is the effect that the researcher would expect to be in the sample was $10 \%$.

Now $\mathrm{n}=\mathrm{n}(\mathrm{n} * 0.15)+(\mathrm{n} * 0.1)=96(96 * 0.15)+(96 * 0.1)=120$ Therefore, sample size was 120 students.

\subsection{The study variables}

The study variables were the dimensions of time management (long range planning, short range planning and time attitudes) in relation with year of study, gender and academic achievement.

\subsection{Data collection method}

The time management questionnaire developed by 'Britton and Tessor (1991) was used to measure time management behavior of participant students. The adopted questionnaire was made up of seven items in the short range planning, six items in the time attitude dimension and five items in the long range planning dimension.

\subsection{Method of data analysis}

After the data was collected, the processing and analysis were done. The questionnaire would be sorted out by using software package/Spss version 21 to analyze the data. Descriptive data analysis method was employed together with qualitative and quantitative interpretation of data. Correlation analysis was also conducted among time management variables. Differences were also tested with chi-square test. Finally the results of the study were expressed using tables.

\section{Results and discussion}

The Level of General Time Management Behavior among Regular Program students of dire dawa University $2^{\text {nd }} \& 3^{\text {rd }}$ year the school of business and economics Regular Program Students, General Time management Level is summarized in the table below. 
Table1.The frequency levels of the pointes related to the general time management (GTM) Levels of Regular program students of Dire Dawa University

\begin{tabular}{|l|l|l|l|}
\hline Level of GTM & Pointes & Frequency & Percentage \\
\hline Low & $<48$ & 33 & $27.5 \%$ \\
\hline Moderate & $48-57$ & 45 & $37.5 \%$ \\
\hline High & $>=58$ & 42 & $35 \%$ \\
\hline Total & & 120 & $100 \%$ \\
\hline
\end{tabular}

Source: (own survey, 2018)

Since the questionnaire distributed was adapted from Britton and tesser (1991), the score Regarding general time management Behavior /practice of students of DDU is based on those who scored 58 and above points have better time management practice, those who scored 48-57 pointes have moderate time management practice and those scored below 48 points have low time management practice. As can be seen in table 1 above , the time management level of regular program dire dawa university students was at allow level (f: $33,27.5 \%$ ) and 45(37.5\%) possessed moderate time management Score and the remaining portion was for high time management score (f: 42, 35\%). These figures underscore that as regarded time management, Majority of students hold moderate and high time management positions and that they have relatively good knowhow about their time usage and using their time in Planned way, by prioritizing the activates and setting goals before they start their work because this activates plays a vital role for being successful.

Table2: Time management behavior of the school of business and economics regular program students on the basis of their gender, year of study and academic achievement.

\begin{tabular}{|c|c|c|c|c|c|c|c|c|c|c|c|c|c|c|}
\hline \multirow{3}{*}{$\begin{array}{l}\text { Time } \\
\text { management } \\
\text { behavior of } \\
\text { students }\end{array}$} & \multicolumn{4}{|c|}{ Gender } & \multicolumn{6}{|c|}{ Academic achievement } & \multicolumn{4}{|c|}{ Year of study } \\
\hline & \multicolumn{2}{|l|}{ Male } & \multicolumn{2}{|c|}{ Female } & \multicolumn{2}{|c|}{$\begin{array}{l}\text { High } \\
\text { achievers }\end{array}$} & \multicolumn{4}{|c|}{ Moderate achievers } & \multicolumn{2}{|c|}{$1^{\text {st }}$ Year } & \multicolumn{2}{|c|}{$2^{\text {nd }}$ Year } \\
\hline & $\mathrm{M}$ & SD & $\mathrm{M}$ & SD & $\mathrm{M}$ & SD & $\mathrm{M}$ & SD & $\mathrm{M}$ & SD & $\mathrm{M}$ & SD & $\mathrm{M}$ & SD \\
\hline GTM & 55.72 & 1.06 & 50.5 & 1.41 & 58.6 & 1.28 & 53.02 & 1.2 & 46.83 & 1.38 & 54 & 1.2 & 54.1 & 1.27 \\
\hline SRP & 21.9 & 0.59 & 19.7 & 0.86 & 24.09 & 0.69 & 20.8 & 0.67 & 16.47 & 0.65 & 21.35 & 0.74 & 21.1 & 0.65 \\
\hline LRP & 16.09 & 0.45 & 14.7 & 0.52 & 16.65 & 0.58 & 14.94 & 0.47 & 14.64 & 0.68 & 15.52 & 0.49 & 15.8 & 0.50 \\
\hline TA & 24.7 & 0.39 & 16.2 & 0.58 & 17.85 & 0.45 & 17.31 & 0.56 & 15.8 & 0.73 & 17.13 & 0.38 & 17.23 & 0.53 \\
\hline
\end{tabular}

Source: (own survey, 2018)

Note: GTM= General Time management

$\mathrm{SD}=$ standard deviation

$\mathrm{SRP}=$ Short range planning

$\mathrm{LRP}=$ long range planning

$\mathrm{TA}=$ Time attitudes

Higher values on the scale correspond to better time management practices. As result shows in the table 2, above indicated male students have better general time management behavior $(\mu$ score $=55.72)$, short range plan implementation $(\mu$ score $=21.96)$, long range plan implementation $(\mu$ score $=16.09)$, time attitude $(\mu$ score $=$ 17.67) than female student. However the overall general time management behavior of male student was categorized as at moderate level since the mean result falls between 48 to 57 time score of Britton and teaser. Even female student have moderate general time management behavior $(\mu$ score $=50.51)$, their practice relatively lower than their male counterparts. This showed that female students are not aware or they lack sufficient knowledge about how to manage their time, again from my experience most of the student prefer recreating or enjoying rather than using their time effectively.

High preforming moderate performing and low performing regular program school of business and economics students have different not only in their academic achievement but also in their general time management behavior/practices. Those who are high academic performance have better time management practice $(\mu$ score $=58.6)$, moderate academic performer have moderate time management practice $(\mu$ score $=$ 53.02) and low academic performer have low time management behavior $(\mu$ score $=46.8)$, high performing student and moderate performing student have relatively superior time attitude $(\mu$ score $=17.8)$ and $(17.31)$ respectively than low performing student (mean score, 15.8). Second and third year student have relatively the same general time management behavior, short range plan implementation. Long range plan implementation, 
time attitude this shows that is no significant difference is observed due to the year. However, the overall general time management behavior of second year students and third year students was categorized as at moderate level since the mean result falls between 48 to 57 time score as Briton and tesser.

Table3: chi-square test on association between gender and time management variables among second and third year students on school of business and economics students of Dire dawa University

\begin{tabular}{|l|l|l|l|}
\hline \multirow{2}{*}{$\begin{array}{l}\text { Time } \\
\text { variables }\end{array}$} & Gender & Df & Significance \\
\cline { 2 - 4 } & $\mathrm{X}^{2}$ calculated & 39 & 0.628 \\
\hline GTM & 35.550 & 22 & 0.575 \\
\hline SRP & 20.121 & 16 & 0.034 \\
\hline TA & 27.7 & 17 & 0.392 \\
\hline TRP & 17.9 & &
\end{tabular}

Source: (own survey, 2015)

Significant at $* \mathrm{p}<$.0.05., two -tailed

The result presented in the table 3 above showed that there is no astatically significant difference between male and female students on general time management, short range planning and a long range planning, where as there is a significant deference between students on time attitude, scores due to their gender. The male students reported greater time management than did the female students relatively. What we understand from the above result or finding is that, male students is better in there time usage than females'. They better knowhow in their time usage compared to female students.

Table 4: chi square test on association between academic achievement and time management variables among second and third year students on school of business and economics students of dire dawa university.

\begin{tabular}{|l|l|l|l|}
\hline \multirow{2}{*}{$\begin{array}{l}\text { Time } \\
\text { variables }\end{array}$} & Academic achievement & significance \\
\cline { 2 - 4 } & $\mathrm{X}^{2}$ calculated value & $\mathrm{Df}$ & 0.016 \\
\hline GTM & 90.34 & 78 & 0.000 \\
\hline SRP & 91.165 & 44 & 0.016 \\
\hline LRP & 39.86 & 32 & 0.0019 \\
\hline
\end{tabular}

Source (own survey, 2018)

Significant at $* \mathrm{p}<.0 .5$ two -tailed

The results presented in the table 4 , above showed that there is statistically significant difference among high achiever, moderate achiever and low achiever students' on general time management, short range planning, time attitudes, and long range planning due to the deference in their academic achievement. If the ability to effectively manage time was indeed positively related to academic performance, than, presumably, interventions that improve time management would be of value to student's (burrus, et al .,2013).

Table 5 chi-square test on association between year of study and time management variables among school of business and economic students of dire dawa university

\begin{tabular}{|l|l|l|l|}
\hline \multirow{2}{*}{$\begin{array}{l}\text { Time } \\
\text { variables }\end{array}$} & Year of study & Significance \\
\cline { 2 - 4 } & X2 calculated value & Df & 0.141 \\
\hline GTM & 48.5 & 39 & 0.300 \\
\hline SRP & 24.9 & 22 & 0.545 \\
\hline TA & 15.7 & 17 & 0.175 \\
\hline LRP & 9.2 & 16 & \\
\hline
\end{tabular}

Source own survey, 2018)

Significant at $* \mathrm{p}<.0 .05$. Two -tailed

With respect to the year of study, the result which listed in table 5 showed that the students' general time management scores was not significantly different between students due to their year of study. As the result showed there is no significant difference on general time management, short range planning, long range planning, $\&$ time attitude due to year of study. This means being second and third year does not create any change on students general time management, short range planning, long range planning, and time attitude.

\subsection{Summary of Findings}

The primary objective of this study was to examine general time management behavior of regular program business and economics, second and third year student of dire dawa university, and also this study aimed to test whether students time management behavior have significance association with students gender, year of study, and academic achievement.

With respect to the gender difference in time management, the results revealed that male student scores in time management $(\mu$ score $=55.7)$ were higher than female $(\mu$ score $=50.5)$ student. This result was not consists with the result of (macan et al., 1990 saketi and taheri, 201, pehlivan 2013, and kaushar, mehnaz (2013). They 
conclude that female student in terms of time management are generally more accomplished than male student and possess higher average score. Male students use time more effectively than female which can be related to the fact that they use and implement more effectively behavior such as listing, planning and programing which are all from the category of traditional time management (Alay \& Kocak, 2001). The difference is not statically significant in all sub-scale (short range planning dimension, and long range time dimension) of the time management scale being male or female student. But there is statically significance difference in time attitude of the time management scale of being male and female student.

With respect to the significance association between time management and academic achievement (CGPA), it is found in this study that the better the students time management behavior, the higher the students CGPA. The result has good consistence with result of Britton \& Tesser, 1991; Misra \& Mckean, 2000; talib, 2012). The deference is also statically significant in all sub-scales (short range planning dimension, time attitude and lone ranger time dimension) of the time management scale being high achiever, moderate achiever or low achiever student in their academic achievement. Both Britton and Tesser (1991) and Macan, et al (1990),reported that a student ability to manage their time successfully and productively is clearly related to academic performance the better a student's time management, the better their grades and the less stress they experience in regards to their academic life.

With respect to the year of study, the result showed that the student general time management scores were not significantly different between students due to their year of sound, since they are senior and there is no much difference about knowing the university situation.

\subsection{Conclusion}

Generally the study underscores the importance of understanding the role/effect of time management on academic achievement. Certainly students who are unable to manage time well may be at risk for underachievement. Time management scores of the student's show the way to score of academic achievement as concluded that students who scored poor in academic achievement gained significantly lower in time- management. There found an association found between time management practices, academic achievements and stress reduction as the research study demonstrated that an association exists between anxiety lessening, practices of time management and higher academic success. Moreover, there is an association between time management abilities and educational outcomes.

\subsection{Recommendation}

The general recommendations are for the three banks considered in this study, which includes;

D Firstly, build the program that provides time management training for the university students. It may help them free themselves from negative consequences of academic achievement which is brought about by the poor time management. Even if most of the students have moderate and high level of general time management, it needs much more works.

$>$ The university has to optimize its capacity to help its students to bring better time management behavior since effective time management seemed to increase academic achievement in this sample.

$>$ Since the one of the strategic theme of the university is assuring academic excellence through improving academic performance of the students and minimizing attrition rate, due attention must be given for time management by the university.

$>$ Being informed of this important linkage, university students should start managing their own time use and learn how to manage time and stress to improve their academic performance.

\section{Recommendations for the future research}

This research emphasizes on the effect of time management practices on academic achievement of students in regular second and third year students of dire dawa university. Therefore future research must be conducted on the other areas like comparative study on extension class and regular class students on the effect of time management and also on the same title on the other universities will be possible.

\section{References}

$>$ Battle, J., \& Lewis, M. (2002). The increasing significance of class: The relative effects of race and socioeconomic status on academic achievement. Journal of Poverty, 6(2), 21-35.

$>$ Macan, T. H., Shahani, C., Dipboye, R. L. \& Phillips, A. P. (2000). College student's time management: Correlations with academic performance and stress. Journal of Educational Psychology, 82 (4), 760-768.

Britton, B. K., \& Tesser, A. (2001). Effects of time management practices on college grades. Journal of Educational Psychology, 83, 405-410.

Britton, B. K., \& Tesser, A. (1991). Effects of time management practices and dimensions. Journal of Educational Psychology, 83, 405-410. 
$>$ Al-Ghamdi, Muhammad (2008): Time Management of Secondary Schools in Taif Managers, Educational Administration and Planning Department, Umm Al Qura University, Saudi Arabia.

$>$ Alsalmi, Fahd Ibn Awad (2008). The Practice of time Management and its Impact on the Development of Administrative Creativity Skills among Secondary School principals. , Faculty of Education, Educational Administration and Planning Department, Umm Al Qura University, Saudi Arabia.

$>\quad$ Abu Sakour, Tyseer Abdalhameed (2003). Obstacles to time management and Decision-Making to the Education Departments of government Secondary Schools in the West Bank, Palestine. A doctoral dissertation in shams university, Egypt.

$>$ Laurie, A., \& Hellsten, M. (2002). What Do We Know About Time Management? A Review of the Literature and a Psychometric Critique of Instruments Assessing Time Management University of Saskatchewan, Canada.

$>$ Alay, S., \& Koçak, S. (2003). Relationship between time management and academic achievement of university students. Kuram ve Uygulamada Eğitim Yönetimi Dergisi, 35, 326-335.

$>$ Brigitte, J. C., Claessens, Eerde, W. V., Rutte, C. G, Roe, R. A. (2005). A review of the time management literature. Emerald Group Publishing Limited, 36 (2), 2007.

$>$ Kelly, M. (2004). Get time on your side, Careers \& Universities, 24 (4), p.28.

$>$ Noftle, E., Robins., \& Richard, W. (2007). Personality predictors of academic outcomes: Big five correlates of GPA \& SAT scores. Journal of Personality and Social Psychology, 93, 116-130.

$>$ Lisa, M., \& Robert, M. S. (2008). I will do it tomorrow: College Teaching. 57 (5), p.21- 2154. Academic One-File, https://www.ebscohost.com[Accessed Oct 4, 2011.

$>$ Kaushar, M. (2013). Study of Impact of Time Management on Academic Performance of College Students. Journal of Business and Management, 9 (6), P 59-60.

$>$ Mercanlioglu. C. (2010), the Relationship of Time Management to Academic Performance of Master Level Students, International Journal of Business And Management Studies, 2 (1), p. 255-276.

$>$ Karim., \& Mitra, K. (2015), Time management skills impact on self-efficacy and academic performance. Journal of American Science, 7(12).

$>$ Saxton, J. (2000). Investment in education: Private and public returns.

$>$ Sabelis, I. (2001), “Time management: paradoxes and patterns". Time \& Society, 10, p- 387-400.Retrieved from http://www.house.gov/jec/educ.pdf.

$>$ Sevari, K., \& Kandy, M. (2011). Time management skills impact on self-efficacy and academic performance. Journal of American Science, 7(12), 720-726.

$>$ Yilmaz, I., Yoncalik, O., \& Bektaş, F. (2006). Relationship between the time management behavior and academic success. E-Journal of New World Sciences Academy, 5(3), 187-194. 